\title{
Website Evaluation for the Local Tourism Offices of Indonesia's Top 10 Priority Destinations
}

\author{
Mohamad Robbith Subandi ${ }^{\text {a }}$, Fajar Kusnadi Kusumah Putra ${ }^{\text {b }}$ \\ ${ }^{a}$ Travel Department, Sekolah Tinggi Pariwisata Bandung, Bandung, Indonesia \\ ${ }^{\mathrm{b}}$ Hospitality Department, Sekolah Tinggi Pariwisata Bandung, Bandung, Indonesia
}

Corresponding author: Tel. +628156087625

E-mail addresses:mrt@stp-bandung.ac.id (Mohamad Robbith Subandi)

\begin{abstract}
The recent growth of Information and Communication Technology (ICT) has a significant impact to people's way of searching and processing information. Increasing number of travelers is using the internet to assist them in planning their journey especially as a source of information. This has made internet as an important destination marketing tool for travel \& tourism organizations including local and national tourism offices. The aim of this study is to provide updated overview of the official websites of local tourism offices or local government in provincial and city or regency's level in which Top 10 Priority Tourism Destination are located, based on the facilities and services offered by the websites. Subsidiary aim of this study is to determine the features that are used most frequently on the Local Tourism offices' websites. This study should be of interest to researchers, government official as well

information regarding the destination; however it lacked facilities or features which allow visitor to interact more with the tourism office or even fellow visitors. The most frequent features available in the evaluated websites are Culture/history information which was the feature with highest percentage (77\%) followed by Contact (email/fax) with (74\%) Picture gallery and use of animated pictures were scored at (71\%) and Newsletter at (68\%), In the bottom of the list are Terms \& Condition, Chatting/News Group, Virtual Postcard at (0\%)or virtually non-existent. The results also show that local tourism offices still have much room for improvement in the term of using the internet to boost and maximize their destination marketing effort. It is recommended that local tourism offices significantly upgrade and modify their official websites into more efficient and effective marketing instrument to exploit the potential internet based market.
\end{abstract} as industry professionals by applying the content analysis on the feature of tourism websites. The findings of the research will enable the local government official to understand how effective their websites in delivering information for the visitors. The results will assist them also in judging website performance against competitors so that they have useful information to facilitate continuous improvement on their own websites. The results indicated that official websites of the local tourism offices already provides sufficient general
Keywords - website evaluation, content analysis, local tourism office tourism information, destination marketing.

Internet has gaining more importance and popularity as an effective tool of searching information of destination these days, tourism and travel information are among the most popular and sought after information in the internet (ZHOU, Q and Desantis, R, 2005) \& (BRONNER, Fred and de Hoog, Robert, 2016) The use of 
Internet in travel planning is also increasing and prevalent (GRETZEL et al., 2008). From a previous research it was identified that official destination websites was used by $93 \%$ of internet user as a source of online information about the destination (LEHTO, X Y et al., 2006) hence it is becoming important for the government and Destination Management Organization or DMO to capitalize on this increasing popularity of internet search among the potential visitors, by putting more attention and allocate more resources towards developing a suitable official websites of the destination, which in this Indonesia context in general are usually manages by the local tourism offices, which may setup a separate website or incorporate it in their official local government websites.

The rationale behind this study is that while there are already a number of studies conducted before on tourism websites analysis, study on local tourism offices websites, especially which related to Indonesia Top 10 Priority Destinations is very limited or non-existent. However there is one particular research previously done on City Culture and Tourism Directorates in Turkey (YAYLI, Ali and Bayram, Murat, 2010) which can be replicated with some modification for the purpose of this study. Therefore this study try to fill the gap by evaluating the local tourism offices websites related to Indonesia's Top 10 Priority Destinations based on the instruments and method used in the research previously conducted on Turkey's City Culture and Tourism Directorates (YAYLI, Ali and Bayram, Murat, 2010)

\section{Literature review}

Destination Management Organization or DMO are non-profit public or private institution responsible for marketing and managing a tourism destination (GRETZEL, Ulrike et al., 2006). To support its function in marketing the destination, more DMO nowadays own an official websites. One of the objectives of its websites is to incorporate its marketing and visitor services strategies into their online activities (YAYLI, Ali and Bayram, Murat, 2010) when DMO website is concerned it is currently become an important marketing and communication tools with travellers or visitors (MORRISON, Alastair M, 2013) As a part of the DMO, local government official websites which are often serve as the official destination website along with official websites of The Ministry of Tourism in the national level, play a critical role in promoting the destinations as well as the individual services and facilities of a destination. Therefore, website's features should be carefully selected and designed (YAYLI, Ali and Bayram, Murat, 2010). There are some methods or approaches to analyze and measure the quality of tourism websites, (LAW, Rob et al., 2010) summarize the methods into these following classification (a) counting, (b) automated, (c) numerical computation, (d)user judgment and (5) combined methods.

The one which is frequently use is content analysis (YAYLI, Ali and Bayram, Murat, 2010) or Web Quality Index (WQI) which is specific website analysis model for tourism industry (MIGUEL-GONZALEZ, Maria Isabel and Fernandez-Cavia, Jose, 2015).

Indonesian central government has set a high target of receiving 20 million international tourists by 2019 (KEMENTERIAN PARIWISATA, 2016) to reach that number Indonesian central government through The Ministry of Tourism employs several strategies one of which is setting up Top 10 Priority Tourism Destination out of 50 National Tourism Destination previously mapped in The National Tourism Development Plan 2011. (KEMENTERIAN PARIWISATA, 2011)

These 10 destinations are Lake Toba, 
Tanjung Kelayang, Seribu Islands, Tanjung Lesung, Borobudur, Bromo, Mandalika, Wakatobi, Morotai and Labuan Bajo. (RATMAN, Dadang Rizki, 2016). Despite this Top 10 Priority Destinations program is actually initiated and belong to The Ministry of Tourism in the national level, at provincial and city or regency level, the organization in charge of destination information is The Department of Tourism or Tourism Offices of the local government. Though the names or nomenclatures may vary in each region but their roles remain the same, as a representative of the local government in tourism sector.

\section{Research methodology}

In Indonesia local tourism offices or department of tourism are part of the local government which in general have bigger authority than the central government in managing the destinations. These local tourism offices with the support of central government mainly through The Ministry of Tourism, and in some part private sectors, plan, set-up, market and manage the destinations collectively. Because of its central role in destination management and as the source of information for tourists the local tourism offices website was chosen for this study. In total there were 32 websites identified for this study, but only 31 websites were evaluated as one website was still under construction at the time of the study and hence omitted from the study.

This study aimed to describe and evaluated the features and information of the websites therefore content analysis method was used in this study as this method was the most commonly used in this kind of research.

Content analysis is used to examine and evaluate the content and function of the websites. This study utilized modified standardized form, and features previously used in similar research conducted on
Turkish Local Tourism City Culture and Tourism Directorates (CCTD) (YAYLI, Ali and Bayram, Murat, 2010). There were 31 indicators used in the evaluation as shown in table 1 below

Table 1

Website Evaluation Checkpoints

\begin{tabular}{|c|}
\hline Features in the Website \\
\hline Culture/history information \\
\hline Call center/Detailed contact \\
\hline Video related to Destination \\
\hline Picture Gallery \\
\hline Information on Transportation \\
\hline Use of animated pictures \\
\hline Link to related Sites \\
\hline Online search in website \\
\hline Contact (email/Fax) \\
\hline Website Map \\
\hline Events Calendar \\
\hline Shopping Information \\
\hline Climate Information \\
\hline Hotel / Accommodations \\
\hline Maps \\
\hline Research data \\
\hline Link to other Tourism Sites \\
\hline Restaurant Information \\
\hline Trip Guide \\
\hline Online Brochure \\
\hline Multilingual Websites \\
\hline Rent a Car \\
\hline Feed Back Form \\
\hline Visitor Comments \\
\hline Search for Packages \\
\hline Newsletter \\
\hline Terms \& Condition \\
\hline Vhatting / News group \\
\hline Registration \\
\hline
\end{tabular}

Each local tourism office websites in provincial and regency level were evaluated by using 1 for availability and 0 for absence as coding in each checkpoint of features. The assessment process involving two assessors, to minimize the 
possibility of personal bias. The evaluation was carried out using both personal computer and notebook with sufficient internet connection, during the evening after office hours. Collected data then analyzed using Statistical Package for Social Science Software.

\section{Research findings and comments}

Table 2

Websites features frequency level

\begin{tabular}{|c|c|c|}
\hline Feature in the Website & $\begin{array}{c}\text { No of } \\
\text { Website }\end{array}$ & $\%$ \\
\hline $\begin{array}{l}\text { Culture/history } \\
\text { information }\end{array}$ & 24 & 77 \\
\hline $\begin{array}{l}\text { Call center/Detailed } \\
\text { contact }\end{array}$ & 22 & 71 \\
\hline $\begin{array}{l}\text { Video related to } \\
\text { Destination }\end{array}$ & 16 & 52 \\
\hline Picture Gallery & 22 & 71 \\
\hline $\begin{array}{l}\text { Information on } \\
\text { Transportation }\end{array}$ & 10 & 32 \\
\hline $\begin{array}{l}\text { Use of animated } \\
\text { pictures }\end{array}$ & 22 & 71 \\
\hline Link to related Sites & 15 & 48 \\
\hline $\begin{array}{l}\text { Online search in } \\
\text { website }\end{array}$ & 18 & 58 \\
\hline Contact (email/Fax) & 23 & 74 \\
\hline Website Map & 2 & 6 \\
\hline Events Calendar & 20 & 65 \\
\hline Shopping Information & 10 & 32 \\
\hline Climate Information & 5 & 16 \\
\hline $\begin{array}{l}\text { Hotel / } \\
\text { Accommodations }\end{array}$ & 16 & 52 \\
\hline Maps & 12 & 39 \\
\hline Research data & 10 & 32 \\
\hline $\begin{array}{l}\text { Link to other Tourism } \\
\text { Sites }\end{array}$ & 11 & 35 \\
\hline $\begin{array}{l}\text { Restaurant } \\
\text { Information }\end{array}$ & 16 & 52 \\
\hline Trip Guide & 15 & 48 \\
\hline Online Brochure & 4 & 13 \\
\hline Multilingual Websites & 8 & 26 \\
\hline Rent a Car & 4 & 13 \\
\hline Feed Back Form & 10 & 32 \\
\hline Visitor Comments & 17 & 55 \\
\hline Search for Packages & 1 & 3 \\
\hline
\end{tabular}

\begin{tabular}{|l|c|c|}
\hline Newsletter & 21 & 68 \\
\hline Currency Information & 0 & 0 \\
\hline Terms \& Condition & 0 & 0 \\
\hline Chatting / News group & 0 & 0 \\
\hline Virtual Postcards & 0 & 0 \\
\hline Registration & 7 & 23 \\
\hline
\end{tabular}

There are some interesting findings in this research; one of the main finding is that no websites scored $100 \%$ in all of the features evaluated, which means none of them have all the features or checkpoints used in the web evaluation. This finding may not come as a surprise for the local tourism offices of the destination in the small and remote areas of Indonesia, due to the limited resources they have but it hardly acceptable for the local tourism office websites of Indonesia's more developed provinces and regency, including DKI Jakarta as the Country's Capital city. There are $(16 \%)$ of the websites that were inaccessible during the evaluation hence they are given 0 for all features evaluated. (13\%) of the local tourism offices evaluated dedicated the whole website as destination or tourism information websites while the rest or $(87 \%)$ still included their governmental daily activity and other governmental information which not directly related to the destination. From the evaluation it can be identified top 11 most frequent features available in local tourism websites, they are Culture/history information which is the feature with highest percentage (77\%) followed by Contact (email/fax) with $(74 \%)$ Picture gallery and use of animated pictures are scored at $(71 \%)$ and Newsletter at (68\%), events calendar (65\%), Online search in websites $(58 \%)$, Visitor Comments (55\%), Video, Hotel and restaurant information at (52\%). In the bottom of the list are Terms \& Condition, Chatting/News Group, Virtual Postcard (0\%) Search for Packages (3\%) Website Map (2\%), Online Brochure and Rent a car $(13 \%)$. The local tourism offices which are part of the local government where the 10 priority destinations are 
located usually eager to showcase more of their 'locality' or local identity to differentiate themselves from other destinations, therefore it was not surprising that most of the websites have Culture/history information provided, some of them even in great details. Ideally they also provided sufficient information on how the unique local identity can contribute to Indonesia's national identity. The use of animated pictures, picture gallery and Video related to destination feature are also of almost equally high percentages $(71 \%)$ and $(52 \%)$ respectively, it could suggested that the local tourism offices already aware of the importance of visual communication, where well-shot photograph or video with attractive animation is actually more alluring and intriguing to visitors than mere text description, however they seems to overlooked the potential of virtual postcard and online brochure in this visual communication process, where none of the evaluated official websites actually provided a virtual postcard for their visitors, and only (13\%) of the websites evaluated provided an online brochure. Call center/detailed contact is also of high percentage $(71 \%)$ They seems aware the risk of misinformation especially for their web visitors who have not been to the destination should be minimized, therefore instead of risking their visitor finding the detailed information from other sources which may be unreliable and bias they consider it is necessary to put clear and detailed contact on their websites to make sure that the interested web visitors received the right information regarding the destination from them.

The availability of link to the related sites and link to other tourism sites features in the websites are quite low $(48 \%)$ and $(35 \%)$ respectively. While most of the related websites links are of the other departments under the same local government, only small part of the evaluated websites were actually provided a link to The Ministry of Tourism official website or to (Indonesia.travel) website which is a tourism promotional websites manages by The Ministry of Tourism. This finding was unforeseen, considering that apart from the fact that the highest authority of the top 10 priority destinations often lies with each local tourism offices as part of the local governments, The Ministry of Tourism as a part of Indonesian central government is actually the main driver and initiator of this 10 national priority destinations program hence until now The Ministry of Tourism is still allocating significant funds and expertise in order to help accelerating the development of all these 10 priority destinations at least until 2019 (RATMAN, Dadang Rizki, 2016). This finding can be a result of mere web design errors but can also indicated the lack of effective collaboration between local government through local tourism offices and The Ministry of Tourism as a part of the central government. Interactivity features in the websites such as visitor comments, feedback form, registration, chatting/ News group features are available in moderate-low percentage (55\%), (32\%), (23\%), (0\%) respectively. Interactivity itself has a significant effect on visitor interest and even to their purchase intention (JIANG, Zhenhui et al., 2010) therefore the local tourism offices should consider to engage with their website's visitors more by adding interactive features on their sites. Apart from Culture/history information (77\%) and newsletter $(68 \%)$ all other informative features are having lower percentage level including event calendar (65\%), hotel/accommodation and restaurant information (52\%), trip guide (48\%), maps (39\%), information on transportation, shopping information and research data $(32 \%)$, climate information (16\%), rent a car (13\%), search for package $(3 \%)$, currency information and terms \& condition (0\%), Ideally these websites should put more effort in providing basic information about the 
destination to the visitor as this information is certainly needed by most of the visitor should they plan to visit the destination. It should be noted that none of the websites evaluated are actually provided any information about local currency; hence the visitor should look for the currency information elsewhere, unless they already have some knowledge about Indonesia's currency as the country where the destination is located. When it comes to term \& condition feature it is quite obvious that none of the websites evaluated have that feature, as all of the websites evaluated do not have reservation or booking feature and only function as source of information on the destination. There are apparently some legal and regulatory constraints that may hinder government owned official websites to integrate a booking engine as one of their features; however the absence of booking feature can be replaced by providing a link to online travel agency or other tourism service provider related to the destination. Lastly there are some features that can help the visitor navigating in the website, such as website map, online search in website, and language options or multilingual websites. These features can provide the visitor with better browsing ease and experience, unfortunately only few local tourism offices are actually incorporated these features into their websites. Most of the websites doesn't provide website map $(6 \%)$ and only few websites $(26 \%)$ are bilingual or multilingual. English, Mandarin, Japanese, Dutch, and Deutsch are some of the international languages option available in few of the websites. The majority of the websites are only using Indonesian language or Bahasa Indonesia. The lack of language options for the visitors of the websites can be highly unfavorable for the websites and the destinations themselves especially if they are planning to attract more international visitors. The overall findings of this study indicated some similarities with the previous study conducted in Turkey (YAYLI, Ali and Bayram, Murat, 2010) This similarity of findings mostly evident in the way that generally the websites evaluated are informative but surprisingly both study indicated the lack of links to the national tourism offices websites are actually provided by the evaluated websites. On the other hand while none of the features in the websites evaluated in this study scored $100 \%$, some of the website features in the previous study are actually scored $100 \%$ or available in all websites evaluated, especially in terms of informative features.

\section{Conclusions and recommendations}

This study was intended to provide updated general picture of local Tourism office websites of Indonesia's Top 10 Priority Destination and identify the most common features in these websites. The study was carried out based on similar research previously conducted on the official websites of City Culture and Tourism Directorates (CCTD) in Turkey. (YAYLI, Ali and Bayram, Murat, 2010). Some features and analytical method from previous study on (CCTD) were also utilized. However this study were not meant to evaluate all of local tourism office websites in Indonesia but only evaluated websites of local tourism office related to Indonesia's Top 10 Priority Destinations. The results of the study indicated that while the websites are generally informative, the local tourism offices of Indonesia's Top 10 Priority Destinations are not using the internet to its full potential especially in marketing their destinations. There should be more interactive features that allow visitor to engage and communicate more and easily with the respective local tourism offices or even with fellow visitors.

Local tourism offices and The Ministry of Tourism should working together more closely and come up with more effective integrated destination marketing scheme 
as both sides actually have equal interest and concern on this 10 Top Priority Destinations, thus a better integrated marketing scheme will prove more beneficial for both of them and the destinations itself. Providing a better experience for the visitor of the websites should also be a focus of the local tourism offices, a website map and more language options are fundamental if they wish to increase the number of their web visitors' especially international visitors. Despite the legal and procedural constrains the local tourism offices should also consider installing reservation or booking engine or feature in their official website as it can simplify the travel decision-making process of the visitors. This will make the website seen as more effective and efficient one-stop tourism service center rather than just information sources website. This study has several limitations, some of them are the data collection only done from local tourism office websites accessible on the time of the study and a number of destinations among the Top 10 Priority destination are actually have their own non-government destination websites which runs or manage by their private company or other non-governmental organization. Some local tourism offices also provide the information of the destinations through blogs instead of websites. Subsequently a future study on this topic should take those non-governments and official blogs into account. The future study should also incorporate more features or indicators and also actually rate and rank the websites using point rating system or other methods deemed suitable.

\section{References}

BRONNER, Fred and Robert DE HOOG. 2016. Travel websites: Changing visits, evaluations and posts. Annals of Tourism Research. 57, pp.94-112.

GRETZEL, Ulrike, Daniel R FESENMAIER, Sandro FORMICA, and
Joseph T O'LEARY. 2006. Searching for the Future: Challenges Faced by Destination Marketing Organizations. Journal of Travel Research. 45, pp.116126.

GRETZEL, ULRIKE, and Kyung Hyan YOO. 2008. Use and impact of online travel reviews. Information and communication technologies in tourism., pp.35-46.

JIANG, Zhenhui, Jason CHAN, Bernard C.Y TAN, and Wei Siong CHUA. 2010. Effects of Interactivity on Website Involvement and Purchase Intention. Journal of the Association for Information Systems. 11(1), pp.34-39.

KEMENTERIAN PARIWISATA. 2011. Rencana Induk. [online]. [Accessed January 2017]. Available from World Wide Web: < ?c=11" http://www.kemenpar.go.id/asp/ringkasan. asp?c=11 >

KEMENTERIAN PARIWISATA. 2016. Rencana Strategis. [online]. [Accessed January 2017]. Available from World Wide Web:

$<$ http://www.kemenpar.go.id/asp/detil.asp ?c=14\&id=3240 >

LAW, Rob, Shanshan QI, and Dimitrios BUHALIS. 2010. Progress in tourism management: A review of website evaluation in tourism research. Tourism Management. 31(3), pp.297-313.

LEHTO, X Y, D Y KIM, and A M MORRISON. 2006. The Effect of prior destination experience on online information search behavior. Tourism and Hospitality Research. 6(2), pp.160-178.

MIGUEL-GONZALEZ, Maria Isabel and Jose FERNANDEZ-CAVIA. 2015.

Tourism and online communication: interactivity and social web in official destination websites. Communication \& Society. 28(4), pp.17-31.

MORRISON, Alastair M. 2013. Marketing and managing tourism destinations. New York: Routledge. 
RATMAN, Dadang Rizki. 2016. Paparan Deputi BPDIP. [online]. [Accessed January 2017]. Available from World Wide Web: http://www.kemenpar.go.id/userfiles/Papa ran\%20-\%20Deputi\%20BPDIP.pdf $>$

YAYLI, Ali and Murat BAYRAM. 2010. Web-based destination marketing: Do official city culture and tourism website' in Turkey consider international guidelines? Tourism: An International Interdisciplinary Journal. 58(1), pp.51-60. ZHOU, Q and R DESANTIS. 2005.

Usability issues in city tourism website design: a content analysis. In: IEEE International Profesional Communiaction Conference Proceedings 

